\title{
Bioethanol production from sago pith waste using microwave hydrothermal hydrolysis accelerated by carbon dioxide
}

\author{
Saravana Kannan Thangavelu ${ }^{\mathrm{a}, \mathrm{c}}$, Abu Saleh Ahmed ${ }^{\mathrm{b}}$, Farid Nasir Ani ${ }^{\mathrm{c}, *}$ \\ ${ }^{a}$ Faculty of Engineering, Computing and Science, Swinburne University of Technology, 93350 Kuching, Sarawak, Malaysia \\ ${ }^{\mathrm{b}}$ Department of Mechanical and Manufacturing Engineering, Faculty of Engineering, Universiti Malaysia Sarawak, Sarawak, Malaysia \\ ${ }^{\mathrm{c}}$ Faculty of Mechanical Engineering, Universiti Teknologi Malaysia, UTM 81310 Skudai, Johor D.T., Malaysia
}

\section{H I G H L I G H T S}

- Microwave hydrothermal hydrolysis with $\mathrm{CO}_{2}$ was carried out for SPW.

- Batch fermentation and distillation was carried out.

- GC and FTIR confirmation of distilled ethanol was done.

- Maximum of $43.8 \%$ glucose and $15.6 \mathrm{~g}$ ethanol per $100 \mathrm{~g}$ SPW was obtained.

- Lower energy consumption was observed for combined pretreatment and hydrolysis.

\section{A R T I C L E I N F O}

\section{Article history:}

Received 16 December 2013

Received in revised form 5 April 2014

Accepted 23 April 2014

Available online 20 May 2014

\section{Keywords:}

Microwave hydrothermal hydrolysis

Carbon dioxide

Sago pith waste

Bioethanol

Energy efficiency

\begin{abstract}
A B S T R A C T
Bioethanol production from sago pith waste (SPW) using microwave hydrothermal hydrolysis accelerated by carbon dioxide was studied. The structural change in the SPW after hydrolysis, ethanol purity after fermentation, and distillation were investigated. Energy consumption for microwave hydrothermal hydrolysis was evaluated. A maximum of $43.8 \%$ theoretical glucose and $40.5 \%$ theoretical ethanol yield were obtained. The ethanol yield coefficient obtained in fermentation was 0.47 ( $\mathrm{g}$ ethanol per $\mathrm{g}$ glucose) which was $15.6 \mathrm{~g}$ ethanol per $100 \mathrm{~g}$ dry SPW. It was also discovered that the lowest energy consumption occurred when energy input was fixed at $108 \mathrm{~kJ}$ ( $900 \mathrm{~W}$ for $2 \mathrm{~min}$ ), amounting to $33 \mathrm{~kJ}$ and $69 \mathrm{~kJ}$ to produce one gram glucose after hydrothermal hydrolysis and one gram ethanol after fermentation, respectively. The developed technique for SPW resulted in higher energy saving compared to previous techniques in the absence of enzymes, acid or base catalyst.
\end{abstract}

(c) 2014 Elsevier Ltd. All rights reserved.

\section{Introduction}

The research on development of renewable and sustainable fuels is an important effort due to shortage of petrochemical fossil fuels and environment pollution [1]. Bioethanol obtained from biomass and bioenergy crops has been proclaimed as one of the feasible alternative to gasoline fuel [2]. Currently, large scale bioethanol production is mainly from sugar containing substances and starch grains, may not be desirable due to their feed value [3]. The lignocellulosic biomass is one of the potential main sources for economic bioethanol production globally. Agricultural, forestry (soft and hardwoods) and industrial wastes are the major lignocellulosic biomasses [4]. In addition, the starchy lignocellulosic biomass such as waste from starch processing factories, potato food factories,

\footnotetext{
* Corresponding author. Tel.: +60 7 5534715; fax: +60 75566159.

E-mail address: farid@fkm.utm.my (F.N. Ani).
}

beverage, and brewery factories are promising feedstock for large scale production in tropical locations [5-9].

The sago pith waste (SPW) or sago 'hampas' is a fibrous starchy lignocellulosic byproduct generated from pith of Metroxylon sagu (sago palm) after extraction of starch [10]. In Sarawak, Malaysia about $50-110 t$ of SPW are produced daily from starch processing factories [11]. Sago pith waste (SPW) contains up to 58\% starch, $23 \%$ cellulose, $9.2 \%$ hemicellulose and $4 \%$ lignin in dry basis $(\mathrm{w} / \mathrm{w})$ which can be used as a favourable starchy lignocellulosic feedstock for bioethanol production [12]. The bioethanol production from lignocellulosic biomass involves different steps such as pretreatment, hydrolysis, fermentation and ethanol recovery [3]. Different pretreatments such as physical, chemical, physico-chemical and biological have been studied in the past decade to alter structural characteristics of lignocellulosic biomass [13]. Hydrolysis is an essential step to produce fermentable sugars which are then fermented into ethanol by microbial biocatalyst [4]. 